\title{
Serum Mucin-Associated Antigen Levels of Cystic Fibrosis Patients Are Related to Their Ages and Clinical Statuses ${ }^{1}$
}

\author{
RALPH C. FRATES, Jr., ROBERT J. FINK, MILICA S. CHERNICK, JOHN O. BROOKS III, \\ VICTOR GINSBURG, AND DAVID D. ROBERTS

\begin{abstract}
Laboratory of Structural Biology [R.C.F., V.G., D.D.R.] and Pediatric Metabolism Branch [M.S.C.], National Institute of Diabetes, Digestive and Kidney Diseases, National Institutes of Health, Bethesda, Maryland 20892, Department of Pediatrics, University of Texas Medical Branch, Galveston, Texas 77550 [R.C.F.], Children's Hospital National Medical Center, Washington, D.C. [R.J.F.], and Department of Psychology, Rice University, Houston, Texas [J.O.B.] 77251
\end{abstract}

\begin{abstract}
Mucin levels are generally elevated in sera from many cystic fibrosis (CF) patients as measured by radioimmunoassay using monoclonal antibody $19-9$, which is directed against the mucin-associated sialyl $\mathrm{Le}^{\mathrm{a}}$ antigen. Antibody 19-9 can only be used to measure mucin-associated antigen levels in those patients who are genetically able to make detectable levels of mucin-associated sialyl $\mathrm{Le}^{\mathrm{a}}$ epitope. Serial studies of 20 patients followed over 35 y showed that their serum mucin-associated antigen levels varied directly with respect to the severity of their disease and inversely with their Shwachman-Kulczycki clinical scores $(p<0.001)$ and Brasfield chest roentgenographic scores $(p<0.02)$. Serum mucin-associated antigen levels in samples from $89 \mathrm{CF}$ patients were generally higher in the older patients $(p<0.025)$. Serum mucinassociated antigen levels of CF patients who were colonized with Pseudomonas aeruginosa did not significantly differ from those of uninfected CF patients. The mean serum mucin-associated antigen level of $\mathrm{CF}$ patients colonized with Pseudomonas was higher than the mean mucin level of six non-CF bronchiectatic patients whose lungs were colonized with Pseudomonas $(p=0.053)$. Serum mucinassociated antigen levels are thus related to CF patients' ages and clinical statuses. (Pediatr Res 25:49-54, 1989)
\end{abstract}

\section{Abbreviations}

ANCOVA, analysis of covariance

CF, cystic fibrosis

$\mathrm{Le}^{\mathrm{a}}$ or Le $(\mathrm{a}+\mathrm{b}-)$, Lewis ${ }^{\mathrm{a}}$ blood group antigen

Le $^{b}$ or Le $(a-b+)$, Lewis ${ }^{b}$ blood group antigen

Le $(a-b-)$, negative for Lewis blood group antigen

Mucins are involved in the pathology of CF (1-3). These glycoproteins, the main solid constituent of mucus, become inspissated and obstruct lumens throughout the respiratory, digestive and reproductive tracts of CF patients $(4,5)$. In 1944, Farber suggested CF should be named "mucoviscidosis" to em-

Received December 28, 1987; accepted September 7, 1988

Correspondence Dr. Ralph C. Frates, Jr., Department of Pediatrics, University of Texas Medical Branch, Galveston, TX 77550.

Supported in part by the NIDDK-Cystic Fibrosis Foundation Joint Program (R.C.F.) and by a National Science Foundation Graduate Fellowship (J.O.B.).

${ }^{1}$ Portions of this report were presented in poster format in 1986 at the 27 th Annual Meeting of the Cystic Fibrosis Club, Bethesda, MD. phasize the role of mucin-secreting tissues in the histopathogenesis of the disease (6). The mucins of CF patients are relatively normal except for their longer carbohydrate chains and higher sulfation as compared to controls (7-13), but the reason for their increased viscosity is unknown. The pathology of cystic fibrosis includes blockage of vital passages by viscid mucus secretions, resulting in the patients' premature deaths $(4,5)$.

Several investigators (14-16) have recently described abnormally high mucin-associated antigen levels in the serum of $\mathrm{CF}$ patients. Our initial impression was that serum mucin-associated antigens originated from CF patients' damaged pancreatic ductal epithelium (14). Indeed, inspissated mucus plugs in the pancreatic ductal system of $\mathrm{CF}$ patients are an almost constant histopathologic feature of the disease even in the neonatal period (4-6, 17-19). Crossley et al. (20) thought pancreatic ductal obstruction caused "back-leakage" (20) of acinar digestive enzymes across the epithelium of ductal lumens and eventually into the plasma of about $90 \%$ of CF neonates (21). Radioimmunoassays for the detection of increased concentrations of pancreatic enzymes such as trypsinogen in the blood of newborns are now widely used as an experimental means to screen neonates for $C F(20-26)$. We thought mucins from CF patients' pancreata might enter their circulatory system by the same pathologic route proposed for pancreatic enzymes.

Unlike the pancreatic enzymes in CF patients' sera $(23,27-$ 29), however, elevated serum mucin-associated antigen levels persisted among several adult CF patients (14). An elevated serum mucin-associated antigen level was reported in one adult $\mathrm{CF}$ without clinical evidence of pancreatic dysfunction (14). Furthermore, some infants lacking pancreatic enzyme elevation in their serum have elevated levels of mucin (16). Because measurements of serum mucin-associated antigen levels have been used to detect and monitor patients with pancreatic adenocarcinoma and other gastrointestinal cancers (30-33), serum mucin-associated antigen levels might also reflect the clinical status of CF patients. In the present study, serum mucin-associated antigen levels were measured in specimens from $89 \mathrm{CF}$ patients and from seven non-CF lung disease patients in order to determine if serum levels related to age and clinical status.

\section{MATERIALS AND METHODS}

Patient selection. There were three groups of patients: 1) CF Serial Sample Group: $20 \mathrm{CF}$ patients from whom at least five blood samples each were available, 2) CF Single Sample Group: 69 CF patients from whom one blood sample each was available, 
and 3) Non CF Lung Disease Group: 7 non CF patients with bronchiectasis from whom one blood sample each was obtained.

The blood samples from the patients comprising the CF serial sample group came from a frozen serum bank at Children's Hospital National Medical Center in Washington, DC. Patients were routinely asked to give blood during regular outpatient clinic visits. At the time of the study, the number of blood samples from an individual $\mathrm{CF}$ patient ranged from $1-9$. We decided to study all patients in the bank for whom a minimum of five repeated samples were available. This number maximized the number of both patients and samples available. A total of 24 patients had contributed five or more blood samples. Of these three patients were deleted because they were Le $(a-b-)$, and one additional patient was deleted because a chest roentgenogram was missing. This left 20 patients for study. At the time the patients were chosen, mucin-associated antigen levels had not been calculated from their blood samples. Of the 100 specimens from these 20 patients, only three were drawn within 1 month of hospitalization. Blood samples were collected during the period 1981-1986.

Single blood samples were drawn from $69 \mathrm{CF}$ patients at the National Institutes of Health and Children's Hospital National Medical Center Washington, DC. All of the CF patients at NIH (30) during 1981-1986 volunteered to have their blood used or drawn for the study. The remaining blood samples come from the frozen serum bank taken from outpatients at Children's Hospital who volunteered to give blood during their routine clinic visits. Some of the NIH patients were about to be hospitalized. Le $(a-b-)$ patients were deleted from the sample. These specimens were also obtained from 1981-1986.

The serum and saliva specimens and brief clinical histories from seven patients with non-CF lung disease were kindly provided by Dr. Michael Knowles, University of North Carolina. The basis of his selection was non-CF patients who had bronchiectasis; six of the seven had also grown Pseudomonas aeruginosa from their sputa. Specimens were obtained under protocols approved by the Human Subjects Committees of the different institutions.

Patient characteristics. All CF patients had repeated sweat chloride concentrations of more than $60 \mathrm{mEq} /$ liter using the method of Gibson and Cooke (34) and had clinical findings appropriate for CF. Patients ranged in age from 1 day to $41 \mathrm{y}$, with an average age of $14 \mathrm{y}, 6$ months. Forty-one females and 48 males were included in the study.

Among the nine male and 12 female CF patients who donated serial samples, ages ranged from 2 months to 17 y 3 months, with an average age of $6 y, 6$ months.

The characteristics and results from seven non-CF control patients are given in detail in Table 1. Except for Patient 2, these patients have grown $P$. aeruginosa of the rough strain (Patients 1 and 4) or mucoid strain (Patients 3, 5, 6, and 7) from their sputum cultures at one time or another. Patient 2 has rheumatoid arthritis, spondylosis, and ulcerative colitis. At the time her seurm sample was obtained, endobronchial biopsies demonstrated mucosal ulcers and extraordinary inflammation. No respiratory pathogens were grown from any of the sputum cultures or bronchial aspirates of patient 2 .

There were four males and three females in the non-CF patient group. Their ages ranged from 32 to $78 \mathrm{y}$, with an average age of $51 \mathrm{y}, 6$ months.

Sample preparation. Blood samples were obtained from $\mathrm{CF}$ outpatients by phlebotomy into vacuum container tubes with separator plugs. The tubes were then centrifuged at $600 \times \mathrm{g}$ for $20 \mathrm{~min}$, and the serum was decanted and stored in 1.5 - $\mathrm{ml}$ plastic Eppendorf tubes (Brinkmann Instruments Co., Westbury, NY) at $-20^{\circ} \mathrm{C}$ within a few $\mathrm{h}$ of collection.

Patients were typed for their Lewis blood group. Crude saliva preparations were typed by means of an RIA as described elsewhere (35) using monoclonal antibodies to the Lewis blood group antigens, $\mathrm{Le}^{\mathrm{a}}$ and $\mathrm{Le}^{\mathrm{b}}$, produced by the hybridoma cell lines $151-$ 6-A7-9 and 143-2-A6-11, respectively (American Type Culture Collection HB8324 and HB8325, Rockville, MD). A few patients were typed by the usual red blood cell hemagglutination method. Only those patients belonging to the Le $(a-b+)$ or Le $(a+b-)$ blood groups were included in the study.

Scoring. A physician unaware of the CF patients' serum mucin-associated antigen measurements retrospectivly reviewed the charts and chest roentgenograms of the 20 patients in the $C F$ serial sample group. For each outpatient visit when a serum specimen was obtained, the physician assigned each patient a Shwachman-Kulczycki clinical score (as modified by Doershuk, et al. (36) and a Brasfield chest roentgenogram score (37).

Mucin assay. Serum specimens were assayed for mucin-associated antigen levels using the "CA 19-9 RIA kit" (Centocor, Malvern, PA). Monoclonal antibody 19-9 detects sialyl Le blood group antigen derivative on mucins in human serum $(38,39)$ (see "Discussion"). Results are given in $\mathrm{U} / \mathrm{ml}$ based on standards supplied by the manufacturer. The relative expression of sialyl $\mathrm{Le}^{\mathrm{a}}$ antigen on mucins varies among individuals and binding of the 19-9 monoclonal antibody is, therefore, not a measure of absolute mucin concentrations.

Characterization of the serum mucin-associated antigen from sera of CF patients. Three types of experiments were performed to characterize the antigen detected by monoclonal antibody 199 in the sera of CF patients. The experiments included gel filtration chromatography on sera on an Sephacryl S-400 column

Table 1. Characteristics of non-CF disease lung disease patients

\begin{tabular}{|c|c|c|c|c|c|}
\hline Patient & Sex & $\begin{array}{l}\text { Age } \\
(y)\end{array}$ & $\begin{array}{l}\text { Lewis blood } \\
\text { group type }\end{array}$ & $\begin{array}{c}\text { Serum mucin-associated } \\
\left.\text { antigen level (sialyl Le } \mathrm{Le}^{\mathrm{a}}\right) \\
(\mathrm{U} / \mathrm{ml})\end{array}$ & Diagnosis and condition \\
\hline 1 & $\mathrm{M}$ & 36 & $\mathrm{Le}^{\mathrm{b}}$ & 9 & $\begin{array}{l}\text { Severe basilar bronchiectasis; } \\
\text { stable }\end{array}$ \\
\hline 2 & $\mathrm{~F}$ & 32 & $\mathrm{Le}^{\mathrm{b}}$ & 80 & $\begin{array}{l}\text { Ulcerative bronchitis; ex- } \\
\text { tremely ill }\end{array}$ \\
\hline 3 & M & 58 & $\mathrm{Le}^{\mathrm{a}}$ & $<8$ & $\begin{array}{l}\text { Upper lung zone bronchiec- } \\
\text { tasis posttuberculosis; sta- } \\
\text { ble }\end{array}$ \\
\hline 4 & $\mathrm{~F}$ & 69 & $\mathrm{Le}^{\mathrm{a}}$ & 46 & $\begin{array}{l}\text { Bronchiectasis; posthospitali- } \\
\text { zation }\end{array}$ \\
\hline 5 & $\mathbf{M}$ & 78 & $\mathrm{Le}^{\mathrm{b}}$ & 40 & $\begin{array}{l}\text { Chronic bronchiectasis; mild } \\
\text { exacerbation }\end{array}$ \\
\hline 6 & $\mathrm{~F}$ & 32 & $\mathrm{Le}^{\mathrm{a}}$ & 9 & $\begin{array}{l}\text { Immotile cilia syndrome; } \\
\text { mild bronchiectasis; stable }\end{array}$ \\
\hline 7 & M & 56 & $\mathrm{Le}^{\mathrm{a}}$ & 9 & $\begin{array}{l}\text { Chronic bronchiectasis; very } \\
\text { few respiratory symptoms }\end{array}$ \\
\hline
\end{tabular}


(Pharmacia, Upsala, Sweden) (39) with further purification and analysis of the antigen by density gradient ultracentrifugation (39-41). Thin-layer chromatography with autoradiography of total lipid extracts from a patient's serum and red blood cells was also completed $(38,39)$. Details of these experiments will be presented in a future publication.

Statistical analyses of serially sampled patients. Five serum samples were selected from $20 \mathrm{CF}$ patients who had previously donated multiple blood samples. Patients had blood samples, Brasfield roentgenogram scores and Shwachman-Kulczycki clinical scores for each clinic visit. Braesfield and ShwachmanKulczycki clinical scores were treated as dependent variables in the subsequent analyses. For each dependent variable, the data were subjected to a one-way ANCOVA in which "time points" (the outpatient CF clinic visits for which scores were assigned) was treated as the within-subjects factor and serum mucinassociated antigen levels as a covariate that changed across the within-subjects factor $(42,43)$. In this way, two ANCOVA were conducted: one using Brasfield roentgenogram scores as the dependent variable and the other using Shwachman-Kulczycki clinical scores as the dependent variable. The time points factor was included in the analyses to account for any increase in scores due to the passage of time. Although time points was a continous measure, its values were categorized because the intervals between clinical visits varied for each patient. The covariate, serum mucin-associated antigen levels, was not introduced into the analyses for the purpose of statistical control, but rather to assess the statistical significance of its contributions to ShwachmanKulczycki scores and Brasfield scores. Thus, unlike the typical interpretation of an ANCOVA, the covariate was the variable of interest, whereas the statistical significance of the main effect was of subsidiary importance.

\section{RESULTS}

Results of serum mucin-associated antigen characterization experiments. Gel chromatography experiments demonstrated elution of the serum mucin antigen as determined by solid-phase RIA $(38,39)$ in the void volume of a Sephacryl S-400 column (39). These antigen-positive fractions were then pooled and further purified by density gradient ultracentrifugation (39-41). These experiments demonstrated that the antigen has a mol wt $>2 \times 10^{6}$ with a density of $1.41 \mathrm{~g} / \mathrm{ml}$ in guanidine and cesium chloride. Immunostaining with monoclonal antibody 19-9 of total lipid extracts from a CF patient's sera and red blood cells did not detect any glycolipid antigen reactive with the antibody, whereas sialyl $\mathrm{Le}^{\mathrm{a}}$ was stained by the antibody $(38,39)$. Taken together, the results of these experiments demonstrate that the serum antigen is of high molecular weight with a density greater than that of a typical protein or glycoprotein $(1.2$ to $1.3 \mathrm{~g} / \mathrm{ml})$ (39) but less than that of a proteoglycan $(>1.5 \mathrm{~g} / \mathrm{ml})(44,45)$, and that the antigen is not a lipid. Thus, the antigen detected by monoclonal antibody $19-9$ in the serum of many CF patients is probably on a mucin.

Results of analyses of $C F$ serial sample group. The means of the variables used in the analyses of covariance are provided in Table 2. The first consideration is the analysis in which the Brasfield scores were treated as the dependent variable. As would be expected, Brasfield scores decreased across time points, giving rise to a main effect of time points, $F(4,75)=9.54, p<0.001$.

Table 2. Mean values for variables used in analyses of covariance

\begin{tabular}{lccccc}
\hline \multirow{2}{*}{ Variable } & \multicolumn{5}{c}{ Time points } \\
\cline { 2 - 6 } & 1 & 2 & 3 & 4 & 5 \\
\hline Shwachman-Kulczycki & 80.25 & 79.10 & 76.90 & 74.30 & 72.70 \\
Brasfield & 19.20 & 18.85 & 18.35 & 17.45 & 17.05 \\
Serum mucin-associated & & & & & \\
$\quad$ antigen levels (U/ml) & 95.03 & 94.55 & 90.05 & 124.4 & 115.7 \\
\hline
\end{tabular}

Serum mucin-associated antigen levels accounted for a statistically significant proportion of the variance of Brasfield scores, $F(1,75)=6.41, p<0.02$. The pooled regression coefficient of serum mucin-associated antigen levels was -0.00594 .

Shwachman-Kulczycki scores exhibited the expected decrease across time points $F(4,75)=5.99, p<0.001$. In addition, serum mucin-associated antigen levels accounted for a statistically significant proportion of variance of Shwachman-Kulczycki scores, $F(1,75)=14.02, p<0.001$. In this analysis, the pooled regression coefficient of serum mucin-associated antigen level was -0.03773 .

Although the above analyses involved two different dependent variables that assessed the severity of $\mathrm{CF}$, the conclusions are the same: serum mucin-associated antigen levels accounted for a significant proportion of the variance of the measure of clinical scores above that accounted for by the passage of time.

Data from representative patient from the group of the $10 \mathrm{CF}$ patients whose clinical scores never changed more than 10 points between clinic visits are presented in Figure $1 D$. The mean serum mucin-associated antigen levels for each of these 10 stable patients ranged from $20-270 \mathrm{U} / \mathrm{ml}$ but generally remained constant. One patient was an exception with a constant clinical score of 95 points over 4 years who had a $180 \%$ increase above her mean mucin-associated antigen level from one visit to the next. Eleven CF patients' clinical scores changed by more than 10 points between clinic visits. Their mean serum mucin levels ranged from 15 to $306 \mathrm{U} / \mathrm{ml}$. The data from three patients from this group are presented in Figure $1 A, B$, and $C$. Unfortunately, there were not enough data to permit statistical analysis of the relation between individual CF patient's clinical scores and the respective serum mucin-associated antigen levels, but an inverse relation seems to exist on inspection of the available data (Fig. $1)$.

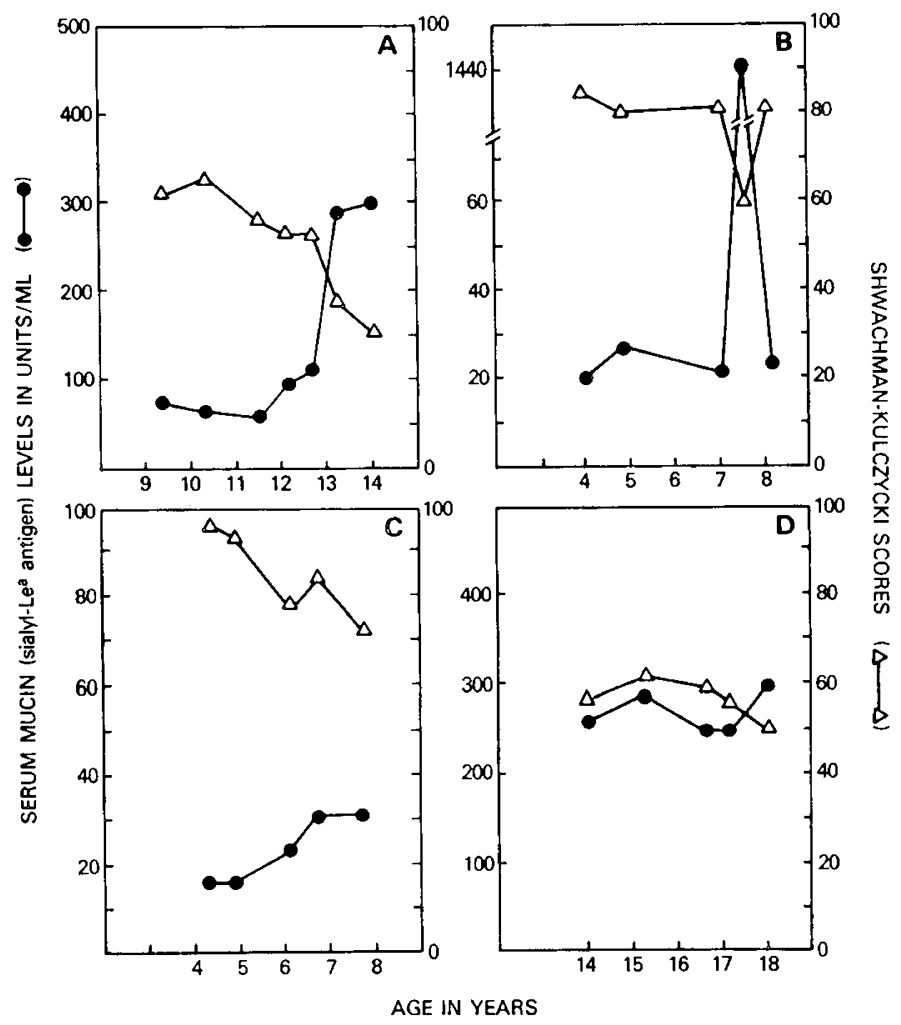

Fig. 1. Changes in serum mucin-associated antigen (Sialyl Le antigen) levels and Shwachman-Kulczycki clinical scores with time. Serum mucin-associated antigen levels $(\bullet)$ and Shwachman-Kulczycki scores $(\triangle)$ are presented for four $C F$ patients who gave serial serum specimens. $A, B$, and $C$ show typical patterns observed in those patients whose clinical status changed during the study. $D$ is representative of those patients whose clinical status did not change significantly. 
Results of analyses of $C F$ single sample group. There was a relation between age and serum mucin levels (Fig. 2). For all 89 $C F$ patients, mucin-associated antigen levels were positively correlated with age, $r(88)=+0.215, p<0.025$ (Fig. 2, line $b$ ). For those $69 \mathrm{CF}$ patients 22 years of age or younger, the correlation was also significant, $r(68),=+0.426, p<0.005$ (Fig. 2, line a).

Elevated serum mucin-associated antigen levels of the 89 patients were not related to respiratory tract infection with $P$. aeruginosa. For the $12 \mathrm{CF}$ patients who never had pseudomonas grown from repeated sputum cultures, the mean $\mathrm{U} / \mathrm{ml}( \pm 1 \mathrm{SD})$ was $194 \pm 359$. For the other $77 \mathrm{CF}$ patients, the mean was 140 \pm 149 . The difference between the groups was not significant, $t(87)=0.514, p>0.05$. For the six nonCF patients with bronchiectasis and pulmonary Pseudomonas colonization or infection, the average serum mucin-associated antigen level was $20 \pm$ $18 \mathrm{U} / \mathrm{ml}$ of serum; their mean serum mucin level was significantly lower than the mean serum mucin-associated antigen level of the Pseudomonas colonized or infected CF group, $t(81)=$ $1.96, p=0.053$. There was no difference between mean serum mucin-associated antigen levels of the six non-CF patients and the pseudomonas-free CF patients, $t(16)=0.53, p>0.05$.

The serum mucin-associated sialyl $\mathrm{Le}^{\mathrm{a}}$ antigen levels for 51 CF patients with known Lewis blood types are provided in Table 3. The six Le $(a+b-)$ patients were evenly divided between the sexes. Of the $45 \mathrm{Le}(\mathrm{a}-\mathrm{b}+)$ patients, there were 24 females and 21 males. Higher levels are generally found in $\mathrm{Le}(\mathrm{a}+\mathrm{b}-)$ patients than in Le $(a-b+)$ patients, whereas Le $(a-b-)$ patients do not make detectable antigen.

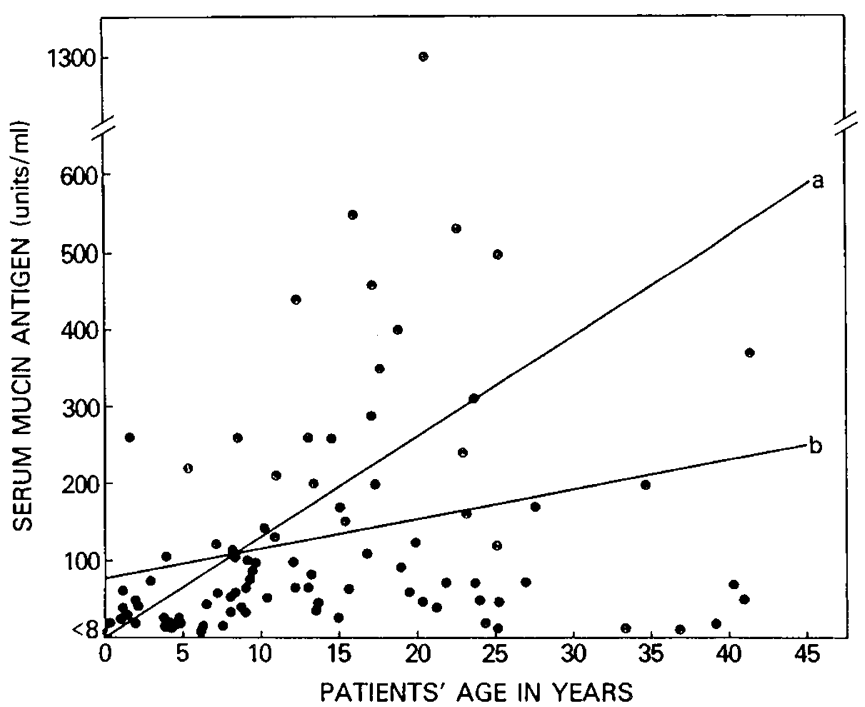

Fig. 2. Correlation of serum mucin-associated antigen levels (Sialyl $\mathrm{Le}^{\mathrm{a}}$ antigen) levels with CF patients' ages. Serum mucin-associated antigen levels determined using monoclonal antibody 19-9 are presented as a function of age for 89 patients belonging to the Le $(a+b-)$ or Le $(\mathrm{a}-\mathrm{b}+)$ blood groups. Regression line $a$ is for patients $22 \mathrm{y}$ old or younger, and line $b$ is for the entire sample.

Table 3. Serum mucin-associated sialyl Le antigen levels in CF patients of Lewis blood groups

\begin{tabular}{lrccc}
\hline \multirow{2}{*}{$\begin{array}{c}\text { Lewis blood group } \\
\text { type }\end{array}$} & $n$ & \multicolumn{4}{c}{$\begin{array}{c}\text { Serum mucin-associated } \\
\text { antigen level }(\mathrm{U} / \mathrm{ml})\end{array}$} \\
\cline { 2 - 5 } & & Mean & Range & SD \\
\hline Le $(\mathrm{a}-\mathrm{b}-)$ & 3 & $<8$ & & \\
Le $(\mathrm{a}+\mathrm{b}-)$ & 6 & 470 & $50-1300$ & 430 \\
Le $(\mathrm{a}-\mathrm{b}+)$ & 45 & 119 & $12-530$ & 131 \\
\hline
\end{tabular}

\section{DISCUSSION}

The ANCOVA show that serum mucin-associated antigen levels of $\mathrm{CF}$ patients were related to their clinical and chest roentgenographic scores. The proportion of variance explained by the Shwachman-Kulczycki scores was higher than that by the Brasfield chest roentgenographic scores. That the relation between serum mucin-associated antigen levels and illness was found using these two different scales attests to the reliability of the finding. However, this difference in the proportion of variance between the two scoring systems may or may not be meaningful because of the differences in these two scales.

The Shwachman-Kulczycki system was modified by Doershuk et al. (36) to enhance its detail. This system awards 25 points in each of four categories: interval symptomatic history, pulmonary physical findings and the nature of the CF patient's cough, growth pattern, and the chest roentgenogram appearance. A perfect score of 100 points means a normal asymptomatic individual. The system is subjective, but it has recently been demonstrated to have "acceptable" interobserver variance (46). The score has not been tested for prognostic value. It is widely used, however, because it does not require pulmonary function test data as does the Taussig-Kattwinkel prognostic scoring system for CF patients (47). Many of the 20 patients in our serial blood sample group were too young for breathing tests when they began participating in the study. By contrast, the 25-point chest roentgenogram scoring system devised by Brasfield et al. $(37,48)$ correlates significantly with pulmonary function tests, and was successfully tested for reproducibility by and between observers. That the scores from this carefully validated system of evaluation correlated so well with the patients' serum mucin-associated antigen levels is particularly encouraging. The ShwachmanKulczycki score's closer association with serum mucin-associated antigen levels may have been due to its inclusion of other aspects of the patient's condition, such as growth pattern, which were omitted from the Brasfield evaluation. Because the time points factor was included in both of the analyses, the relation between serum mucin-associated antigen levels and the two dependent variables (Shwachman-Kulczycki and Brasfield scores) could not be attributed to the progression of the disease over time.

Serum mucin-associated antigen levels increased with the age of $\mathrm{CF}$ patients (Fig. 2). Interestingly, the correlation of serum mucin levels with age was greater for those patients $22 \mathrm{y}$ of age or younger $(+0.426)$ than for older patients $(+0.215)$. The median survival age for CF patients in the United States is about 26 y (49). The association of lower serum mucin-associated antigen levels with the longer-lived group suggests that mucin levels may be of prognostic value in the long-term evaluation of CF patients.

To be a clinically useful test, serum mucin-associated antigen levels must reflect changes in the individual patient's clinical situation. Figure 1 illustrates that serum mucin-associated antigen levels reflected the clinical courses of four patients. The small number of serial serum specimens available from each patient precluded statistical analyses of individual patients. For many of the CF patients tested so far, however, mucin-associated antigen levels were inversely related to their individual condition.

The assay using monoclonal antibody 19-9 does not measure absolute levels of mucin and, therefore, levels among various patients cannot be compared. This results in part from phenotypic variation of Lewis blood group antigen expression. Monoclonal antibody $19-9$ recognizes the sialyl $\mathrm{Le}^{\mathrm{a}}$ antigen, whose structure is NeuAc $\alpha$ 2-3 Gal $\beta$ 1-3[Fuc $\alpha$ l-4]GlcNAc $\beta$ 1-3 Gal. . . (38). The antigen is associated with mucins in the serum of cancer patient (39) and of CF patients (Roberts D, Rose M, Wang W, Chernick M, Frates $D$, manuscript in preparation). $C F$ patients who belong to the Le $(a-b-)$ blood group were excluded from the statistical analyses. These individuals, who comprise 
about $7 \%$ of the general population, do not have a $L e$ gene that specifies the glycosyltransferase responsible for the synthesis of the Fuc $\alpha \mathrm{l}-4 \mathrm{GlcNAc}$ linkage (50), and that is required for the synthesis of the sialyl Le ${ }^{\mathrm{a}}$ antigen (51). All Le $(\mathrm{a}+\mathrm{b}-)$ and most Le $(a-b+)$ individuals can make the sialyl $\mathrm{Le}^{\mathrm{a}}$ antigen, but some Le $(a-b+)$ individuals do not make detectable levels probably because of enzyme competition for precursors $(35,47,50,51)$.

The present results are consistent with these findings as shown in Table 3. The six Le $(a+b-)$ CF patients had average mucinassociated antigen levels four times higher than those of the 45 Le $(a-b+)$ cystic fibrosis patients. Those patients who were Le $(\mathrm{a}-\mathrm{b}-)$ did not have detectable sialyl Le $\mathrm{L}^{\mathrm{a}}$ antigen in their serum. Use of monoclonal antibody 19-9 underestimates serum mucin levels for many patients who are not Le $(a+b-)$. Antibodies directed against serum mucin-associated antigens other than the sialyl Le $\mathrm{L}^{\mathrm{a}}$ carbohydrate group may be used with those patients genetically unable to make detectable levels of sialyl $\mathrm{Le}^{\mathrm{a}}$ antigen (52).

The results presented here are from blood samples drawn months apart and do not address the issue of how promptly serum mucin-associated antigen levels rise or fall in response to changes in the patients. The concentration of mucin-associated antigens in the sera of cystic fibrosis patients depends on the relative rates for their entry into and clearance from the bloodstream. These rates and the site of clearance are unknown.

Because sialyl $\mathrm{Le}^{\mathrm{a}}$ antigen is normally present on mucins in the lung (53) as well as the pancreas (54), salivary glands (35, 54), milk (55), seminal fluid (56), and gut (54), serum mucinassociated antigen could arise from several sources. The pancreas is not the exclusive source of mucin-associated antigens in serum because high serum mucin-associated antigen levels do not depend on pancreatic function. Four CF patients who had insulindependent diabetes, a condition which includes almost complete pancreatic destruction including mucin-secreting ductal epithelia (57) had elevated serum mucin-associated antigen levels. The negative correlation between mucin-associated antigen levels and Brasfield scores suggests that the lung is a significant source of the antigen in serum. Results with two patients also suggest that the lung contributes to serum mucin-associated antigen levels. Both patients had sudden increases in their serum mucin-associated antigen levels, one seven times and the other about 70 times (Fig. $1 B$ ) their respective baseline values. Concurrent with these increases were increased respiratory symptoms and worsened chest examination findings. One patient had a collapsed right middle lobe seen on chest roentgenogram at the time of her serum mucin-associated antigen spike. The other patient had a history of right upper lobe atelectasis and auscultatory dullness of that area of her chest, but no roentgenogram was taken on that visit. Both patients serum mucin-associated antigen levels returned to their previous positions with resolution of symptoms, and the one patient's chest roentgenogram showed expansion of the right middle atelectatic lobe. We suspect that other organ sources than the lung may also be important.

The measurement of serum mucin-associated antigen levels may be a promising way of monitoring the illness of some CF patients. Based on measurements of serum mucin levels from more than 2000 normal donors $(30,32), 95 \%$ of the normal population have serum mucin levels less than $20 \mathrm{U} / \mathrm{ml}$ and $99.5 \%$ have serum mucin levels less than $37 \mathrm{U} / \mathrm{ml}$. In contrast, only 12 of the 89 Lewis-positive CF patients (13\%) had serum mucin levels less than $20 \mathrm{U} / \mathrm{ml}$ and $21(23 \%)$ had less than 37 $\mathrm{U} / \mathrm{ml}$. Only $2 \%$ of 664 patients who had many different acute and chronic nonmalignant diseases, including pancreatitis, inflammatory bowel disease, and intestinal polyps, had serum mucin levels greater than $37 \mathrm{U} / \mathrm{ml}(30,31)$, and 38 of 39 patients with nonmalignant liver disease had mucin levels $<40 \mathrm{U} / \mathrm{ml}$ (32). Elevated serum mucin concentrations comparable to those of CF patients have been found to occur in approximately $80 \%$ of patients with pancreatic adenocarcinoma and approximately
$50 \%$ of patients who have gastrointestinal carcinomas, diseases unlikely to be confused with CF.

Serum mucin-associated antigen levels seem to be independent of tracheobronchial flora in CF patients, as there was no difference between those CF patients who had $P$. aeruginosa grown from their repeated sputa cultures and those $\mathrm{CF}$ patients whose cultures were consistently negative for this organism. Furthermore, the six nonCF lung disease control patients who had bronchiectasis and whose lungs were exposed to proteases of $P$. aeruginosa and other inflammatory products had a lower mean serum mucin-associated antigen level than did CF patients with Pseudomonas in their lungs $(p=0.053)$, suggesting that some other variable(s) than the presence of $P$. aeruginosa alone was responsible for high serum mucin-associated antigen levels. This finding is important because other biochemical markers of pulmonary injury, such as elastase and other enzymes $(58,59)$ and circulating immune complexes (60-63) are related to lung infections with Pseudomonas.

Unlike the available clinical scoring systems, measurements of serum mucin-associated antigens are objective and do not require physicians' time, pulmonary function tests, or x-ray exposure. Although there are other biochemical tests which reflect $\mathrm{CF}$ patients' clinical statuses and correlate with poor lung function and mortality rates [e.g. serum $\operatorname{IgG}(62)$ and immune complexes $(60,61)]$, there is no information on the ready reversibility of serum IgG levels from one clinic visit to the next as is seen with serum mucin levels. Circulating immune complexes, while they are clearly associated with sicker patients, cannot be used for short-term prognosis (63). Perhaps serum mucin-associated antigen level determinations will eventually be useful in patient evaluation if the many present problems concerned with their use can be resolved.

We conclude that the antigen detected by monoclonal antibody 19-9 in high levels in the serum of many CF patients is the sialyl Le $\mathrm{L}^{\mathrm{a}}$ carbohydrate on what probably are mucin molecules. Serum mucin-associated antigen levels depend on CF patients' ages and clinical statuses. Serum mucin-associated antigen level changes in CF patients probably reflect pulmonary mucosal damage, and are not closely related to the presence of $P$. aeruginosa in patients' respiratory tracts.

Acknowledgments. The authors are indebted to Amy Clayton, B.S.N., for collecting specimens, to Centocor, Incorporated, Malvern, PA, for generously providing some CA 19-9 kits, and to Dr. Sarah Burnett for critical review of the manuscript. We are especially grateful to Dr. Michael Knowles, University of North Carolina, who provided control patient samples and clinical histories.

\section{REFERENCES}

1. di Sant'Agnese PA, Talamo RC 1967 Pathogenesis and physiopathology of cystic fibrosis of the pancreas: fibrocystic disease of the pancreas (Mucoviscidosis). N Engl J Med 277:1287-1294

2. di Sant'Agnese PA, Davis PB 1976 Research in cystic fibrosis. N Engl J Med 295:481-485

3. Boat TF, Dearborn DG 1984 Etiology and pathogenesis: the macromolecular secretory product. In: Taussig LM (ed) Cystic Fibrosis. Thieme-Stratton Inc, New York, pp 26-36

4. Oppenheimer EH, Esterly JR 1975 Pathology of cystic fibrosis: review of the literature and comparison with the autopsied cases. Perspec Pediatr Pathol 2:241-278

5. Bedrossian CWM, Greenberg SD, Singer DB, Hansen J, Rosenberg HS 1976 The lung in cystic fibrosis: a quantitative study including prevalence of pathological findings among different age groups. Hum Pathol 7:195-204

6. Farber S 1944 Pancreatic function and disease in early life. V. Pathologic changes associated with pancreatic insufficiency in early life. Arch Pathol 37:238-250

7. Boat TF, Kleinerman JI, Carlson DM, Maloney WH, Matthews LW 1974 Human respiratory tract secretions, I, mucous glycoproteins secreted by cultured nasal polyp epithelium from subjects with allergic rhinitis and cystic fibrosis. Am Rev Respir Dis 110:428-441

8. Boat TF, Cheng PW, Iyer RN, Carlson DM, Polony L 1978 Human respiratory 
tract secretions. Mucous glycoproteins of nonpurulent tracheo-bronchial secretions and sputum of patients with bronchitis and cystic fibrosis. Arch Biochem Biophys 177:95-104

9. Lamblin G, Lafitte JJ, Lhermitte M, Degand P, Roussel P 1977 Mucins from cystic fibrosis sputum. Mod Probl Paediatr 19:153-164

10. Frates RC Jr, Kaizu T, Last JA 1983 Mucus glycoproteins secreted by respiratory epithelial tissue from cystic fibrosis patients. Pediatr Res 17:30-34

11. Wesley A, Forstner J, Qureshi R, Mante M, Forstner G 1983 Human intestinal mucin in cystic fibrosis. Pediatr Res 17:65-69

12. Izutsu K, Johnson D, Shubert M, Wang E, Ramsey B, Tamarin A, Trulove E, Ehsign W, Young M 1985 Electron microprobe analysis of human labial gland secretory granules in cystic fibrosis. J Clin Invest 75:1951-1956

13. Chace KV, Leahy DS, Martin R, Carubelli R, Flux M, Sachdev GP 1983 Respiratory mucous secretions in patients with cystic fibrosis: relationship between levels of highly sulfated mucin component and severity of disease. Clin Chim Acta 132:143-55

14. Roberts DD, Monsein DL, Frates RC Jr, Chernick MS, Ginsburg V 1986 A serum test for cystic fibrosis using monoclonal antibody 19-9. Arch Biochem Biophys 245:292-294

15. Duffy MJ, O’Sullivan F, McDonnel TJ, Fitzgerald MX 1985 Increased concentrations of the antigen CA 19-9 in serum of cystic fibrosis patients. Clin Chem 31:1245-1246

16. Buamah PK, Cornell C, Cassels-Smith AJ 1986 Concentrations of trypsin, elastase, and carbohydrate antigen CA $19-9$ in serum of cystic fibrosis patients. Clin Chem 32:913

17. Imrie JR, Fagan DG, Sturgess JM 1979 Quantitative evaluation of the development of the exocrine pancreas in cystic fibrosis. Am J Pathol 95:697-708

18. Oppenheimer EH, Esterly JR 1973 Cystic fibrosis of the pancreas: morphological findings in infants with and without diagnostic pancreatic lesions. Arch Pathol Lab Med 96:149-154

19. di Sant'Agnes PA, Hubbard VS 1984 The pancreas. In: Taussig LM (ed) Cystic Fibrosis. Thieme-Stratton Inc, New York, pp 230-295

20. Crossley JR, Elliot RB, Smith PA 1979 Dried-blood spot screening for cystic fibrosis in the newborn. Lancet 1:472-474

21. Taussig LM, Boat TF, Dayton D, Fost N, Hammond K, Haltzman N, Johnson W, Kaback MM, Kennel DJ, Rosenstein BJ, Stolz WS, Trause MA, Beal RJ, Keramidas SL 1983 Committee report: Neonatal screening for cystic fibrosis: position paper. Pediatrics 72:741-745

22. Crossley JR, Berryman CC, Elliot RB 1977 Cystic fibrosis screening in the newborn. Lancet 2:1093-1095

23. Davidson AGF, Wong LKT, Kirby LT, Applegarth DA 1984 Immunoreactive trypsin in cystic fibrosis. J Pediatr Gastroenterol Nutr 3(suppl1):S79-88

24. Crossley JR, Smith PA, Edgar BW, Gluckman PD, Elliot RB 1981 Neonatal screening for cystic fibrosis, using immunoreactive trypsin assay in dried blood spots. Clin Chim Acta 113:111-121

25. Heeley AF, Heeley ME, King DN, Kuzemko JA, Walsh MP 1982 Screening for cystic fibrosis by dried blood spot trypsin assay. Arch Dis Child 57:1821

26. Wilcken B, Brown ARD, Urwin R, Brown DA 1983 Cystic fibrosis screening by dried blood spot trypsin assay: results in 75,000 newborns. J Pediatr 102:383-387

27. Cleghorn G, Benjamin L, Coery M, Forstner G, Dati F, Durie P 1985 Agerelated alterations in immunoreactive pancreatic lipase and cationic trypsinogen in young children with cystic fibrosis. J Pediatr 107:377-381

28. Durie PR, Largman C, Brodrick JW, Johnson JH, Gaskin KJ, Forstner GG, Geokas MC 1981 Plasma immunoreactive pancreatic cationic trypsinogen in cystic fibrosis: a sensitive indicator of exocrine pancreatic dysfunction. Pediatr Res 15:1351-1355

29. Bollbach R, Becker M, Rothauwe HW 1985 Serum immunoreactive trypsin and pancreatic lipase in cystic fibrosis. Eur J Pediatr 144:167-170

30. Del Villano BC, Brennan S, Brock P, Bucher C, Liu V, McClure M, Rake B, Space S, Westrick B, Schoemaker H, Zurawski VR Jr 1983 Radioimmunometric assay for a monoclonal antibody-defined tumor marker, CA 19-9. Clin Chem 29:549-552

31. Gupta MK, Rose A, Bocci L, Tubbs R, Bukowki R, Deodhar SD 1985 Measurement of a monoclonal antibody-defined antigen (CA 19-9) in the sera of patients with malignant and nonmalignant disease: comparison with carcinoembryonic antigen. Cancer 56:277-283

32. Ritts RE, Del Villano BC, Go VLW, Herherman RV, Klug TL, Zurawski VR Jr 1984 Initial clinical evaluation of an immunoradiometric assay for CA 19-9 using the NCI serum bank. Int J Cancer 33:339-345

33. Sears HF, Herlyn M, Del Villano BC, Stephlewski Z, Koprowski H 1982 Monoclonal antibody detection of a circulating tumor-associated antigen, II a longitudinal evaluation of patients with colorectal cancer. J Clin Immunol 2:141-149

34. Gibson LE, Cooke RE 1959 Test for concentration of electrolytes in sweat in cystic fibrosis of the pancreas utilizing pilocarpine electrophoresis. Pediatrics 23:545-549

35. Brockhaus M, Wysocka M, Magnani JL, Steplewski Z, Koprowski H, Ginsburg V 1985 Normal salivary mucin contains the gastrointestinal cancer-associ- ated antigen detected by monoclonal antibody 19-9 in the serum mucin of patients. Vox Sang 48:34-38

36. Doershuk CF, Matthew LW, Tucker AS, Nudelman $H$, Eddy $G$, Wise $M$ Spector S 19645 year clinical evaluation of a therapeutic program for patients with cystic fibrosis. J Pediatr 65:677-693

37. Brasfield D, Hicks G, Soong S, Tiller RE 1979 The chest roentgenogram in cystic fibrosis: a new scoring system. Pediatrics 63:24-29

38. Magnani JL, Nilsson B, Bockhaus M, Zopf D, Steplewski Z, Koprowski H, Ginsburg V 1982 A monoclonal antibodydefined antigen associated with gastrointestinal cancer is a ganglioside containing sialylated lacto- $\mathrm{N}$-fucopentaose II. J Biol Chem 257:14365-14369

39. Magnani JL, Steplewski Z, Koprowski H, Ginsburg V 1983 The gastrointestinal and pancreatic cancer-associated antigen detected by monoclonal antibody $19-9$ in the sera of patients is a mucin. Cancer Res 43:5489-5492

40. Starkey BJ, Snary D, Allen A 1974 Characterization of gastric mucoprotein isolated by equilibrium density-gradient centrifugation in caesium chloride. Biochem J 141:633-639

41. Charvey PR, Rupar CA, Gallinger S, Petrunka CN, Strasberg SM 1986 Qualitative and quantitative comparison of gall bladder mucus glycoprotein with and without stones. Gut 27:374-381

42. Jennrich R, Sampson P, Frane J 1985 Analysis of Variance. In: Dixon WJ (ed) BMDP Statistical Software Manual. University of California Press, Berkeley, pp 359-390

43. Winer BJ 1971 Statistical Principles in Experimental Design (2nd ed). McGrawHill, New York, p 806

44. Hascall VC, Kimura JH 1982 Proteoglycans: isolation and characterization Methods Enzymol 82:769-800

45. Iozzo RV, Wight TN 1982 Isolation and characterization of proteoglycans synthesized by human colon and colon carcinoma. J Biol Chem 257:1113511144

46. Lewiston N, Moss R, Hindi R, Rubenstein S, Sullivan M 1987 Interobserver variance in clinical scoring for cystic fibrosis. Chest 91:878-882.

47. Taussig LM, Kattwinkel J, Friedewald WT, di Sant'Agnese PA 1973 A new prognostic score and evaluation system for cystic fibrosis. J Pediatr 82:380 390

48. Brasfield D, Hicks G, Soong S 1980 Evaluation of scoring system. AJR 134:1195-1198

49. Patient Registry Data 1986, Cystic Fibrosis Foundation, Bethesda, MD

50. Grollman EF, Kobata A, Ginsburg V 1969 An enzymatic basis for Lewis blood types in man. J Clin Invest 48:1489-1494

51. Hansson GC, Zopf D 1985 Biosynthesis of the cancer-associated sialyl-Le antigen. J Biol Chem 260:9388-9392

52. Frates RC Jr, Roberts DD, Gaur PK, Ginsburg V 1986 Monoclonal antibody CCK 061 detects mucins in the serum of cystic fibrosis patients. Fed Proc 45:1984(abstr)

53. Watanabe M, Hirohasi S, Shimosato Y, Ino Y, Yamada T, Teshima S, Sekine $\mathrm{T}$, Abe O 1985 Carbohydrate antigen defined by a monoclonal antibody raised against a gastric cancer xenograft. Jpn J Cancer Res (Gann) 76:43-52

54. Arends JW, Verstynen C, Bosman FT, Hilgers J, Steplewski Z 1983 Distribution of monoclonal antibody-defined monosialoganglioside in normal and cancerous human tissues: an immunoperoxidase study. Hybridoma 2:219229

55. Hanisch FG, Uhlenbruck G, Dienst C, Stottrop M, Hippauf E 1985 CA 125 and CA 19-9: two cancer-associated sialylsaccharide antigens on a mucus glycoprotein from human milk. Eur J Biochem 149:323-330

56. Hanisch FG, Uhlenburch G, Dienst C 1984 Structure of tumor-associated carbohydrate antigen CA 19-9 on human seminal-plasma glycoproteins from healthy donors. Eur J Biochem 144:467-474

57. Iannucci A, Mukai Y, Johnson D, Burke B 1984 Endocrine pancreas in cystic fibrosis: an immunohistochemical study. Hum Pathol 15:278-284

58. Desgrandchamps D, Waldvogel FA 1986 Levels of free granulocyte elastase in bronchial secretions from patients with cystic fibrosis: effect of antimicrobial therapy against Pseudomonas aeruginosa. J Infect Dis 153:902-909

59. Goldstein W, Doring G 1986 Lysosomal enzymes from polymorphonuclear leukocytes and proteinase inhibitors in patients with cystic fibrosis. Am Rev Respir Dis 134:49-55

60. Moss RB, Hsu YP, Lewiston NJ $1981{ }^{125} \mathrm{I}$-Clq-binding and specific antibodies as indicators of pulmonary disease activity in cystic fibrosis. J Pediatr 99:215222

61. Wisnieski JJ, Todd EW, Fuller RK, Jones PK, Dearborn KG, Boat TF, Naff GB 1985 Immune complexes and complement abnormalities in patients with cystic fibrosis. Increased mortality associated with circulation immune complexes and decreased function of the alternative complement pathway. Am Rev Respir Dis 133:648-652

62. Wheeler B, Williams M, Matthew WJ, Colten HR 1984 Progression of cystic fibrosis lung disease as a function of serum immunoglobulin $G$ levels: a 5 year longitudinal study. J Pediatr 104:695-699

63. Disis ML, McDonald TL, Colombo JL, Kobayaski RH, Angle CR, Murray S 1986 Circulating immune complexes in cystic fibrosis and their correlation to clinical parameters. Pediatr Res 20:385-390 